\title{
Varietal Resistance of Wheat to the Rice Weevil (Sitophilous oryzae) under Stored Condition
}

\author{
Rajan Sagar Chaudhary ${ }^{1}$, Tej Pratap Dubey ${ }^{2}$ and Rajendra Regmi ${ }^{3}$ \\ ${ }^{1}$ Purbanchal University, Nepal \\ ${ }^{2}$ Banaras Hindu University, India \\ ${ }^{3}$ Agriculture and Forestry University, Nepal \\ DOI: 10.29322/IJSRP.11.09.2021.p11737 \\ http://dx.doi.org/10.29322/IJSRP.11.09.2021.p11737
}

\begin{abstract}
To evaluate the level of resistance of five wheat varieties: Achyut, N.L.971, Bijaya, N.L.297 and Gautam against Sitophilus oryzae (L.), research was carried out at the Entomology laboratory of Nepal Polytechnic Institute, Purbanchal University, during June 2017 to October 2017. Completely Randomized Design (CRD) was used with four replications under a temperature of $30 \pm 5^{\circ} \mathrm{C}$ and relative humidity of $80 \pm 5 \%$. A sample of $500 \mathrm{gm}$ of wheat grains were kept in a plastic jar of $1 \mathrm{~kg}$ capacity. Each treatment was inoculated with 10 pairs of male and female weevils. The parameters of resistance were weevil population build-up, moisture content and damaged grains and that were recorded at the interval of a month. The result showed highly significant differences $(\mathrm{P} \geq 0.05)$ among the tested varieties. After the four months of storage, on the basis of grain infestation and weevil population build-up, Gautam was the most susceptible variety, whereas Achyut, N.L.971 and N.L.297 were found statistically similar among themselves and the least affected by the rice weevil, Bijaya was found to be intermediate in response to the pest attack. Achyut, N.L.971 and N.L.297 being less damaged by weevil so could be the best option to reduce use of chemical fumigants.
\end{abstract}

Key words: Varietal Resistance, Sitophilus oryzae L., Wheat grains storage

\section{INTRODUCTION}

The top cereals produced in the world in 2019, ranked on the basis of tonnage (in million tons), are corn (1099), wheat (734), rice (milled, 495), barley (140), Sorghum (58). (Statista, 2019). Wheat and rice are the most important crops in the world, accounting for more than $50 \%$ of the world's cereal production. Wheat is a staple food globally, which contributes about $20 \%$ of energy intake in the human diet (FAO, 2018). Wheat contributes about $7.14 \%$ of Agriculture Gross Domestic Product (AGDP) in Nepal (Pandey \& Basnet, 2018). Wheat (Triticum aestivum L.) belongs to the Gramineae family. It originated from south western Asia. Wheat is one of the oldest and most important of the cereal crops. It is the principal winter crop and third important cereal crop after rice and maize in Nepal. It is called "Gahun" in Nepali. Wheat is grown in all three domains (agro-climatic regions) of the country, ranging from sea level to $4000 \mathrm{~m}$. These vary in characteristics such as plant height, growing time, grain, protein content, ability to resist cold,drought, disease and pests (Acharya, 2019).

The rice weevil,Sitophilus oryzae (L.) (Coleoptera: Curculionidae), is the most significant insect that damages rice grains in storage(Nwaubani et al., 2014). Reduced grain weight, loss of nutritional value and germination, contamination by mites and fungus, and loss of economic value of the crop all cause damage (Souza et al., 2012). Pest management of stored rice grain has primarily been chemical, with phosphine being the most often used pesticide (Ribeiro et al. 2003; Hossain et al. 2014). However, the development of S. oryzae resistance to these products hinders its control, and additional methods are required for its management (Lee et al., 2001; Ribeiro et al., 2013). Integrated pest management (IPM) is regarded as the most sustainable method of managing pests in stored grains (Ribeiro et al., 2003). Plant resistance, an IPM component, suppresses pest population density below the economic damage thre shold without adding farmer expenses and is compatible with other pest management approaches (Seifi et al., 2013).

Resistance to insects in stored grains can manifest as antibiosis, in which a grain characteristic influences the biology of the insect, increasing mortality and decreasing lifetime, reproduction, and damage. Alternatively, the grain may exhibit antixenosis, which affects insect behaviour, often leading in decreased feeding and oviposition (Lara, 1991; Smith, 2005). The bracts that surround the grain are among the characteristics that give resistance to $S$. oryzae. The bracts surround the grain and are made up of a palea and a lemma. The presence of S. oryzae in stored grains is affected by the aperture (fissure) in the bracts (Ribeiro et al., 2012).

This publication is licensed under Creative Commons Attribution CC BY. 
Another factor contributing to resistance to stored grain pests is the presence of amylase inhibitors. A high lipid content and the presence of amylase inhibitors prolonged the life cycle of S. zeamais and impacted resistance in rice grains (Marsaro et al., 2005).

It has previously been suggested that resistant cultivars might be used to suppress $S$. oryzae and other stored grain insects (Sousa et al., 2010; Bottega et al., 2012). However, there have been few comprehensive investigations to evaluate resistance to $S$. oryzae in wheat cultivars in Nepal. Based on oviposition preference by free choice test and adult emergence test results, the varieties GW 496, GW 11 and GW 322 were found to be less susceptible to S. oryzae, while GW 173, GW 366, and LOK 1 were found to be moderately susceptible, and the only variety HD 2189 was found to be highly susceptible (Arve et al., 2014).

\section{MATERIALS AND METHODS}

The study to assess the degree of resistance of five varieties of wheat against rice weevil consists of the following heading.

\section{1) Method and Materials}

The experiment was conducted at the Entomology lab in Nepal Polytechnic Institute, Purbanchal University. Five different wheat varieties were collected from the National Wheat Research Center, Bairahawa, Nepal. The varieties were selected because those are grown commercially by farmers in Chitwan, Nepal.

\section{2) Insect Rearing}

Insects were raised in $5 \mathrm{~L}$ capacity glass containers with a $7 \mathrm{~cm}$ diameter mouth covered in organdy and closed with a screw lid. Containers containing grains of a commercial rice variety (Sava Mansuli) were kept in a controlled environment $\left(30^{\circ} \mathrm{C}\right.$ and $\left.80 \% \mathrm{RH}\right)$ for 30days for mass rearing.

\section{3) Weevil Inoculation}

The five varieties of wheat were sun dried for a whole day for sterilization and to reduce moisture percent of grain. The moisture of the grains was maintained at $12 \pm 1 \% .10$ pairs of each male and female weevil were released in each container. Male and female weevils were separated based on the length and breadth of the snout and ridges with the help of stereoscopes holding weevils in suction pipes. When compared to males, the female rostrum was much longer and thinner. The female's longer and thinner rostrum structure, in particular, is adapted to make a deep excavation for hiding eggs inside grains (Moon, 2015).

\section{4) Observation and Data recording}

Twenty five gram of sample from each replication was taken out every month for observing different parameters: grain moisture percentage, bored and un-bored grain numbers, and weevil population. Using the data, further parameters were determined:

a) Grain damage $(\%)=($ number of damaged grains / total number of grains $) \times 100$

b) Weight loss (\%):

$$
\text { Percent weight loss }=\frac{(\mathrm{UNd}-\mathrm{DNu})}{\mathrm{U}(\mathrm{Nd}+\mathrm{Nu})} \times 100 \%
$$

Where, $\mathrm{U}=$ weight of undamaged grains in the sample, $\mathrm{D}=$ weight of damaged grains in the sample, $\mathrm{Nu}=$ number of undamaged grains in the sample, $\mathrm{Nd}=$ number of damaged grains in the sample

The percent damage and percent weight loss were calculated using the formula described by Ahmad and Ahmad (2002). The relative humidity and moisture content of grains were recorded during experiment via. Relative Humidity Meter PCE-444 and Digital Moisture Meter (Model No. AG-72).Bored and un-bored grain numbers were observed and recorded directly by counting methods.

\section{5) Statistical Analysis}

First data was tabulated in Microsoft Excel (Ms-Excel) and statistically analyzed by using the R-Studio package. Treatment means were separated by Duncan's Multiple Range Test (DMRT) at 5\% level of significance. The tables and graphs were prepared using the result of statistical analysis.

\section{RESULTS}

\section{1) Grain damage percentage}

The percentage of grain damage recorded at different days after storage of grains was significantly different $(\mathrm{P} \geq 0.05)$ among the tested varieties. At 30 DAS the highest grain damage was recorded in Gautam (4.61\%). The grain damage percent was statistically 
similar among Achyut (0.87\%), N.L.971 (1.50\%), Bijaya (1.67\%) and N.L.297 (1.49\%). Finally at 120 DAS, Gautam recorded the highest grain damage (76.03\%) followed by Bijaya (41.25\%). N.L.971 $(11.93 \%)$ had the lowest grain damage percent which was statistically similar to Achyut (16.29\%) and N.L. (16.38\%).

Table 1: Grain damage percent caused by rice weevil in different varieties of wheat at laboratory condition

\begin{tabular}{|c|c|c|c|c|}
\hline \multirow[t]{2}{*}{ Treatments } & \multicolumn{4}{|c|}{ Grain damage $(\%)$} \\
\hline & 30DAS & 60DAS & 90DAS & 120DAS \\
\hline Achyut & $\begin{array}{c}1.507^{\mathrm{b}} \\
(1.059)\end{array}$ & $\begin{array}{c}3.257^{\mathrm{b}} \\
(1.119)\end{array}$ & $\begin{array}{c}4.842^{\mathrm{c}} \\
(0.720)\end{array}$ & $\begin{array}{l}16.297^{\mathrm{c}} \\
(1.414)\end{array}$ \\
\hline N.L.971 & $\begin{array}{c}0.870^{\mathrm{b}} \\
(1.036)\end{array}$ & $\begin{array}{c}5.165^{\mathrm{b}} \\
(1.179)\end{array}$ & $\begin{array}{c}7.907^{\mathrm{c}} \\
(0.932)\end{array}$ & $\begin{array}{l}11.937^{\mathrm{c}} \\
(1.337)\end{array}$ \\
\hline Bijaya & $\begin{array}{c}1.615^{\mathrm{b}} \\
(1.063)\end{array}$ & $\begin{array}{c}8.997^{\mathrm{a}} \\
(1.277)\end{array}$ & $\begin{array}{l}16.782^{b} \\
(1.228)\end{array}$ & $\begin{array}{l}41.255^{b} \\
(1.709)\end{array}$ \\
\hline N.L.297 & $\begin{array}{c}1.492^{\mathrm{b}} \\
(1.053)\end{array}$ & $\begin{array}{c}3.440^{\mathrm{b}} \\
(1.125)\end{array}$ & $\begin{array}{c}8.877^{\mathrm{c}} \\
(0.935)\end{array}$ & $\begin{array}{l}16.387^{\mathrm{c}} \\
(1.420)\end{array}$ \\
\hline Gautam & $\begin{array}{c}4.617^{\mathrm{a}} \\
(1.162)\end{array}$ & $\begin{array}{c}9.705^{\mathrm{a}} \\
(1.292)\end{array}$ & $\begin{array}{l}41.255^{\mathrm{a}} \\
(1.621)\end{array}$ & $\begin{array}{l}76.032^{\mathrm{a}} \\
(1.934)\end{array}$ \\
\hline Mean & 2.0185 & 6.113 & 15.933 & 32.382 \\
\hline $\mathrm{CV}(\%)$ & 4.829 & 4.202 & 13.402 & 3.144 \\
\hline SEM & 1.178 & 1.662 & 4.115 & 5.879 \\
\hline $\operatorname{LDS}_{0.05}$ & 2.313 & 2.748 & 4.324 & 5.168 \\
\hline F value & $0.026 *$ & $0.0202 * * *$ & $7.85 \mathrm{e}-11 * * *$ & $1.66 \mathrm{e}-13 * * *$ \\
\hline
\end{tabular}

DAS: Days after Storage, CV: Coefficient of variation, LSD: Least significant difference. Values with the same Letters in a column are not significantly different at $5 \%$ by DMRT and the figure in parenthesis indicates square root transformation $(\mathrm{x}+0.5)^{1 / 2}$.

\section{2) Weight loss percentage}

The weight loss percent recorded at different days after storage of grains was significantly $\operatorname{different}(\mathrm{P} \geq 0.05)$ among the tested varieties. At 30 DAS the highest weight loss was recorded in Gautam (2.35\%) and weight loss percent among Achyut $(0.31 \%)$, N.L.971 (0.25\%), Bijaya $(0.22 \%)$ and N.L.297 $(0.2 \%)$ were statistically similar. At 120 DAS highest weight loss was in Gautam(36.73\%) followed by Bijaya(18.91\%), whereas the lowest weight loss was found in N.L.971(5.13\%) which was statistically similar with Achyut(7.12\%) and N.L.297 (7.13\%) varieties of wheat.

Table 2: Weight loss caused by rice weevil in different varieties of wheat at laboratory Condition.

\begin{tabular}{lcccc}
\hline Treatments & \multicolumn{4}{c}{ Weight loss percentage } \\
& 30DAS & 60DAS & 90DAS & 120DAS \\
\hline \multirow{2}{*}{ Achyut } & $0.3132^{\mathrm{b}}$ & $1.219^{\mathrm{b}}$ & $2.055^{\mathrm{c}}$ & $7.125^{\mathrm{c}}$ \\
& $(1.013)$ & $(1.049)$ & $(1.080)$ & $(1.230)$ \\
\multirow{2}{*}{ N.L.971 } & $0.258^{\mathrm{b}}$ & $2.607^{\mathrm{b}}$ & $3.281^{\mathrm{c}}$ & $5.135^{\mathrm{c}}$ \\
& $(1.012)$ & $(1.09)$ & $(1.121)$ & $(1.178)$
\end{tabular}




\begin{tabular}{|c|c|c|c|c|}
\hline Bijaya & $\begin{array}{c}0.227^{b} \\
(1.009)\end{array}$ & $\begin{array}{l}1.608^{b} \\
(1.064)\end{array}$ & $\begin{array}{l}10.546^{b} \\
(1.310)\end{array}$ & $\begin{array}{l}18.916^{b} \\
(1.452)\end{array}$ \\
\hline N.L.297 & $\begin{array}{c}0.205^{b} \\
(1.008)\end{array}$ & $\begin{array}{l}2.412^{b} \\
(1.090)\end{array}$ & $\begin{array}{l}4.938^{c} \\
(1.164)\end{array}$ & $\begin{array}{l}7.133^{\mathrm{c}} \\
(1.232)\end{array}$ \\
\hline Gautam & $\begin{array}{l}2.356^{\mathrm{a}} \\
(1.088) \\
\end{array}$ & $\begin{array}{l}4.683^{\mathrm{a}} \\
(1.166) \\
\end{array}$ & $\begin{array}{l}18.739^{a} \\
(1.457) \\
\end{array}$ & $\begin{array}{l}36.730^{\mathrm{a}} \\
(1.668) \\
\end{array}$ \\
\hline Mean & 0.672 & 2.506 & 7.912 & 15.007 \\
\hline CV $(\%)$ & 3.059 & 3.207 & 4.718 & 4.718 \\
\hline SEM & 0.405 & 0.517 & 2.851 & 6.795 \\
\hline $\operatorname{LDS}_{0.05}$ & 1.357 & 1.533 & 3.599 & 5.556 \\
\hline F value & $0.0152 *$ & $0.00221 * *$ & $2.79 \mathrm{e}-07 * * *$ & $1.26 \mathrm{e}-08 * * *$ \\
\hline
\end{tabular}

DAS: Days after Storage, CV: Coefficient of variation, LSD: Least significant difference. Values with the same letters in a column are not significantly different at $5 \%$ by DMRT and the figure in parenthesis indicates square root transformation $(x+0.5)^{1 / 2}$.

\section{3) Weevil Population Build-up}

Weevil population recorded at different days after storage of grains was significantly different $(\mathrm{P} \geq 0.05)$ among the tested varieties. At 30DAS the highest weevil population was recorded in Gautam (2.7) and Bijaya (2) followed by Achyut (1.1), whereas N.L.971 (0.05) and N.L.297 (0.5) had the lowest weevil population. At 120DAS, Gautam recorded with the highest weevil population (111.25) followed by Bijaya (90), whereas the lowest weevil population was recorded in N.L.971 (20.25) which was statistically similar with Achyut (21) and N.L.297 (25).

Table 3: Weevil population build-up on different varieties of wheat at Laboratory Condition.

\begin{tabular}{|c|c|c|c|c|}
\hline \multirow{2}{*}{ Treatments } & \multicolumn{4}{|c|}{ Weevil population(No\25g) } \\
\hline & 30DAS & 60DAS & 90DAS & 120DAS \\
\hline \multirow[t]{2}{*}{ Achyut } & $1.00^{\mathrm{bc}}$ & $3.25^{\mathrm{c}}$ & $6.25^{\mathrm{b}}$ & $21.00^{c}$ \\
\hline & (1.18) & (1.923) & $(2.523)$ & (4.624) \\
\hline \multirow[t]{2}{*}{ N.L.971 } & $0.05^{\mathrm{c}}$ & $2.75^{\mathrm{c}}$ & $12.00^{\mathrm{b}}$ & $20.25^{c}$ \\
\hline & $(0.965)$ & (1.688) & (3.361) & (4.531) \\
\hline \multirow[t]{2}{*}{ Bijaya } & $2.00^{\mathrm{ab}}$ & $9.25^{\mathrm{b}}$ & $25.00^{\mathrm{b}}$ & $90.50^{\mathrm{b}}$ \\
\hline & (1.56) & (3.09) & (5.034) & (9.53) \\
\hline \multirow{2}{*}{ N.L.297 } & $0.50^{\mathrm{c}}$ & $3.00^{\mathrm{c}}$ & $16.23^{\mathrm{b}}$ & $25.00^{c}$ \\
\hline & $(0.962)$ & $(1.86)$ & (3.474) & $(5.011)$ \\
\hline \multirow{2}{*}{ Gautam } & $2.75^{\mathrm{a}}$ & $15.50^{\mathrm{a}}$ & $71.25^{\mathrm{a}}$ & $111.25^{\mathrm{a}}$ \\
\hline & $(1.756)$ & $(3.98)$ & $(8.392)$ & $(10.5691)$ \\
\hline Mean & 1.35 & 6.75 & 26.2 & 53.6 \\
\hline CV (\%) & 19.8 & 18.2034 & 18.199 & 7.073614 \\
\hline SEM & 0.225 & 2.375 & 90.35 & 16.15 \\
\hline LDS $_{0.05}$ & 1.011035 & 3.284784 & 20.25999 & 8.565669 \\
\hline F value & $0.000737 * * *$ & $1.25 \mathrm{e}-06 * * *$ & $3.89 \mathrm{e}-05 * * *$ & $2.28 \mathrm{e}-13 * * *$ \\
\hline
\end{tabular}

DAS: Days after Storage, CV: Coefficient of variation, LSD: Least significant difference. Values with the same letters in a column are not significantly different at $5 \%$ by DMRT and the figure in parenthesis indicates square root transformation $(\mathrm{x}+0.5)^{1 / 2}$. 


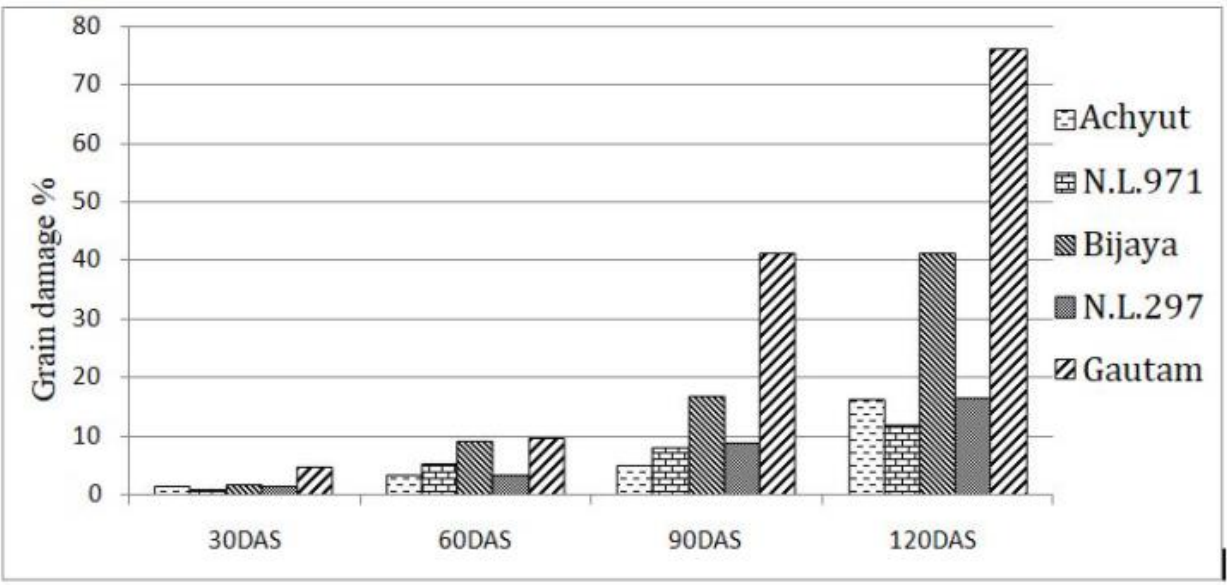

Figure1: Performance of different wheat varieties for grain damage caused by rice weevil

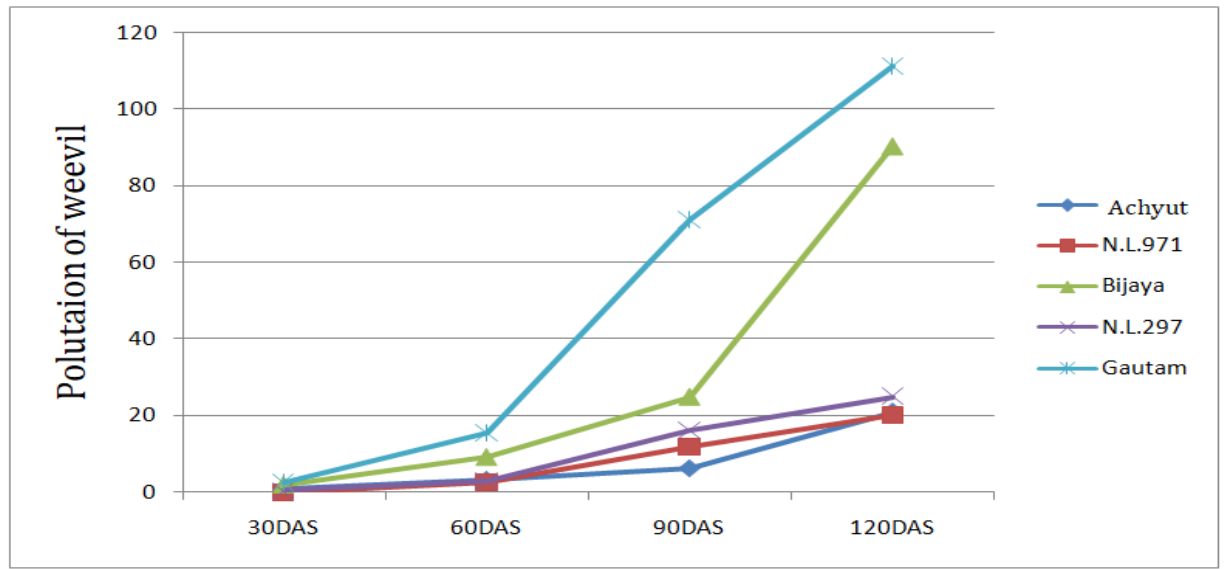

Figure2: Weevil Population Build-up in different varieties of wheat

\section{DISCUSSION}

In my findings there was a highly significant positive correlation between adult population, percent infestation and percent grains damaged. The same positive correlation has been reported between pest population increase, grain weight loss and grain moisture by (Ahmad \& Ahmad, 2002; Suleiman et al., 2013; Yadav et al., 2018).Basis of different parameters, comparatively Achyut, N.L.971 and N.L.297 were found to be similar among them and least affected by the rice weevil, whereas Gautam was the most susceptible variety and Bijaya was found to be intermediate in response to the pest attack.

\section{CONCLUSION}

There was a highly significant positive correlation between adult population, percent infestation and percent grains damaged. Hybrid varieties comparatively have less incidence of rice weevil than the local genotypes. This may be attributed to genotypic character having thick pericarp. Both the susceptible varieties i.e. Gautam and Bijaya have comparatively thinner pericarp than other tested varieties. Therefore, it is suggested not to store the varieties for a long time in storage. Cultivating and using store-insects-tolerating varieties would be the best alternative methods of using hazardous insecticides.

\section{ACKNOWLEDGEMENTS}

Authors would like to convey their heartfelt appreciation to Nepal Polytechnic Institute, Purbanchal University, Nepal, for the financial support for this research. We truly appreciate different authors and publishers, to whom we have referred to in the text.

\section{REFERENCES}

Ahmad, M. and Ahmad, A., 2002. Storage of food grains. Farm. Outl., 1: 16-20.

This publication is licensed under Creative Commons Attribution CC BY. 


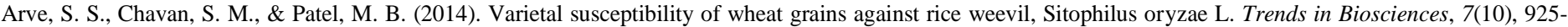
934

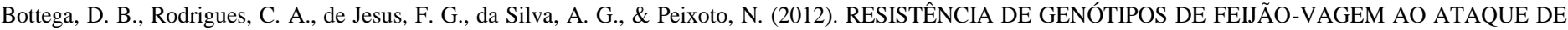
BRUQUÍ-NEOS, EM CONDIÇÕES DE LABORATÓRIO. Revista Caatinga, 25(1), 92-97.

Chunni, R., \& Singh, V. S. (1996). Resistance to Sitophilus oryzae in wheat and associated grain characteristics. Indian Journal of Entomology, 58(1), 79-90.

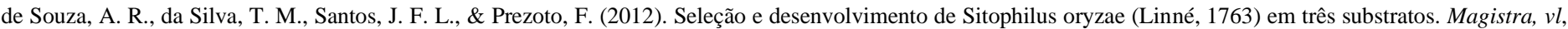
$24,160-163$

FAO (2018) FAOSTAT database. Retrieved from http://faostat.fao.org/ . Accessed 8 sept. 2020

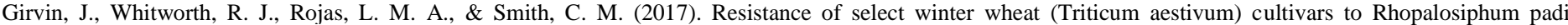
(Hemiptera: Aphididae). Journal of Economic Entomology, 110(4), 1886-1889.

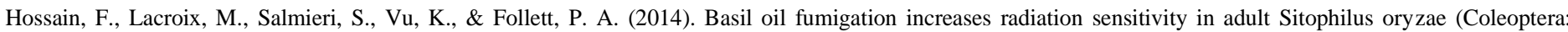
Curculionidae). Journal of Stored Products Research, 59, 108-112.

Lara, F. M. (1991). Princípios de resistência de plantas a insetos.

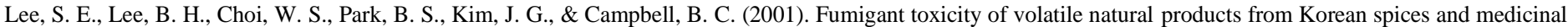
plants towards the rice weevil, Sitophilus oryzae (L). Pest Management Science: formerly Pesticide Science, 57(6), 548-553.

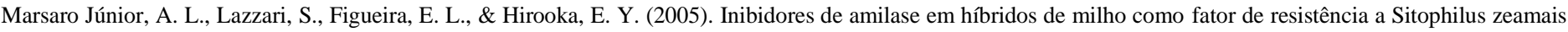
(Coleoptera: Curculionidae). Neotropical Entomology, 34, 433-450.

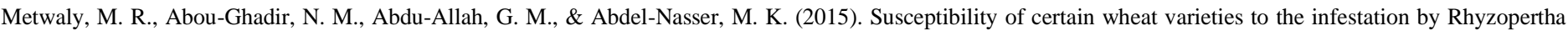
dominica (F.) and Tribolium confusum (du Val). Journal of Phytopathology and Pest Management, 1-8.

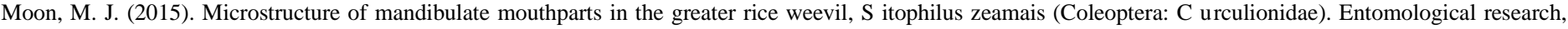
$45(1), 9-15$.

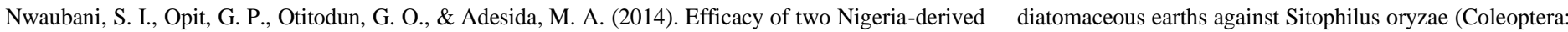
Curculionidae) and Rhyzopertha dominica (Coleoptera: Bostrichidae) on wheat. Journal of Stored Products Research, 59, 9-16.

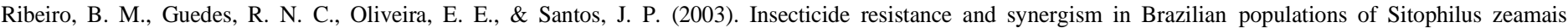
(Coleoptera: Curculionidae). Journal of Stored Products Research, 39(1), 21-31.

Seifi, A., Visser, R. G. F., \& Bai, Y. (2013). How to effectively deploy plant resistances to pests and pathogens in crop breeding. Euphytica, 190(3), $321-334$.

Smith, C. M. (2005). Plant resistance to arthropods: molecular and conventional approaches. Springer Science \& Business Media.

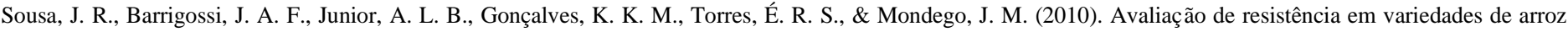
(Oryza sativa 1.) ao ataque do Sitophilus oryzae linnaeus, 1763 (coleoptera: curculionidae). Nucleus, 7(1), 1-8.

Statista, (2019). Worldwide production of grain by type, 2018/19. Retrieved from https://www.statista.com/statistics/263977/world-grain-production-by-type/

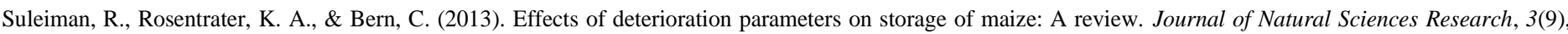
147-165.

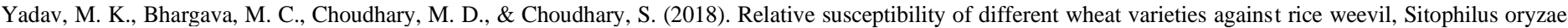
(Linn.). Journal of Entomology and Zoology Studies, 6(2), 2877-2879.

\section{AUTHORS}

First Author: Mr. Rajan Sagar Chaudhary, Bachelor's degree (Honours) in Agriculture, Purbanchal University, Nepal, Email: rajandang031@gmail.com

Second Author: Mr. Tej Pratap Dubey, Master's degree in Agriculture (Agronomy), Department of Agronomy, Institute of Agricultural Sciences, Banaras Hindu University, Varanasi, UP, India. Email: ctevt.tej@gmail.com

Third Author: Mr. Rajendra Regmi, Assistance Professor, Department of Entomology, Agriculture and Forestry University, Nepal, Email: rregmi@afu.edu.np

Corresponding Author: Mr. Rajan Sagar Chaudhary, Bachelor's degree (Honours) in 
International Journal of Scientific and Research Publications, Volume 11, Issue 9, September 2021

Agriculture, Purbanchal University, Nepal,

Email: rajandang031@gmail.com 